\title{
Making mega-space for others: Towards theology of mega-friendship from the table fellowship story according to Luke 5:27-32
}

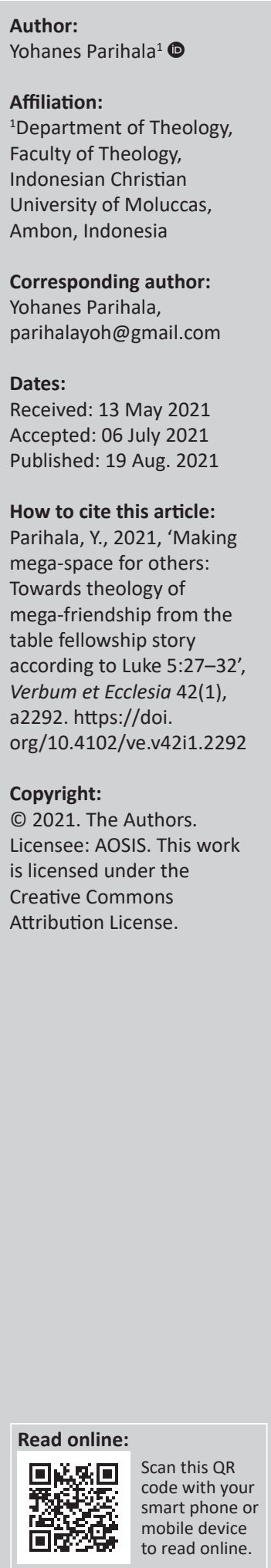

The purpose of the article is to interpret the story of the table fellowship in the Gospel of Luke 5:27-32 and construct the theology of mega-friendship with the Other in the context of a pluralistic society. What is happening in the present is that human communities should be living together and facing the fact of differences in the races, ethnic groups, cultural entities or religious communities. In this context, there is a kind of global fear of strangers, rejection of others and conflict or violence against those who differ. By interpreting the text, I argue that Christianity is called to participate in the mega-friendship created by God by making megaspace and befriending the Other. Mega-friendship in the table fellowship is to sustain life in love, equality, compassion, peace and transformation. The theology's construction begins by explaining the socio-historical context of the table fellowship story, exposing the meaning of the story and constructing the theology of mega-friendship in the context of a pluralistic society.

Intradisciplinary and/or interdisciplinary implications: This research has interdisciplinary implications. It departs from New Testament studies to constructive theology by using a pluralism perspective. By interpreting the table fellowship story in Luke 5:27-32, there is a meaning of the text on theology of friendship and its relevance as a sign of Christian presence in the pluralistic society of the Indonesian context.

Keywords: The gospel of Luke; table fellowship; mega-space; mega-friendship; the other; plurality.

\section{Introduction}

Religions today are facing sharp criticism from scientists, who at the same time identify as new moralists or atheists. They argue that religious differences are often seen as the root cause of violent clashes around the world. As careful as authors such as Juergensmeyer (2017) or Cavanaugh (2009) might be when nuancing the relationship between religion and violence, hamfisted agnostic and atheist critiques, such as those offered by Hitchens (2009), Dawkins (2008) and Harris (2004), continue to exert considerable influence on the public imagination (Case 2019:6-7). In Galtung's (1996:2) analysis, religious teachings can be an ideological tool to legitimise direct acts of violence or structural violence. This criticism of religion is related to the role and influence of different religions in a pluralistic society.

Pluralistic society refers to the human community that lives together in different entities and identities, including ethnicity, culture, social groups, religions, etc. In the context of this plurality, Joas Adiprasetya mentioned that the global fear of the stranger, self-immunity and rejection of the Other seems to be a favourite way of life in plural societies. The faces of strangers are often seen as enemies, even monsters, rather than as neighbours or friends (Adiprasetya 2018:185). Meanwhile, in the book Stranger or Co-Pilgrims? Ariarajah (2017:35-38) mentions five perspectives on the Other, namely: the other as a threat, the other as different, the other as an alternative, the other as a part of my own reality and the other as partner or co-pilgrims. The first three perspectives see the Other as a source of tension, conflict and hostility. The last two perspectives are the solutions offered to build dialogue and cooperation between religious communities. Ariarajah (2017) then wrote about the necessity to create religious dialogue:

What is happening in our day is that human communities are being thrown together in unprecedented ways by population movement and the forces of globalization. By the races, ethnicities, groups, cultural entities, or religious communities, they all challenged to live in close proximity to each other and to participate together in a number of dimensions of life, especially in economic and political fields. Much of 
the tension between religious communities today may well have to do with this enforced proximity and the need to find social, economic, political, and spiritual space to be themselves. It is the attempt to deal with this reality that has brought interfaith dialogue into vogue. (p. 34)

Ariarajah's idea of the human community being together is also a social reality of Indonesian society. However, what is said as the enforced proximity is different from Indonesian society's historical reality. As a pluralistic country, Indonesia is known as a nation that consists of many traditional societies with great social, ethnic, cultural and religious diversity. Bhineka Tunggal Ika, which means diversity in unity, is the national motto that becomes the foundation for the establishment of the Indonesian state. However, it cannot be denied that until now, there are still conflicts, discrimination and various practices of violence with religious nuances in various regions in Indonesia.

Conflict is one of the realities in a plural society like Indonesia. Parihala and Busro (2020) mention:

It is difficult to unify a country as wide as Nusantara that has 17.508 islands, with citizens from two great races (Malay and Melanesia), over 350 tribes speaking in 583 dialects, and embracing the five major religions of the world. The varieties of these cultures and geographical conditions make that the Nation of Indonesia easier becomes fragile. (p. 5)

Religious pluralism is very often used as an instrument of conflict. Asnath Niwa Natar describes that various conflicts in Indonesia were purely criminal, which then escalated into conflict issues between tribes and led to religious war. The existing conflicts are not religious conflicts, but religion is used for political interests (Natar 2019:5). Yusak B. Setyawan explained that what was in the conflict was not the religion, but the organisation and its adherents. In other words, what happened was a conflict that used the name of religions that were still spreading in Indonesia (Setyawan 2017:1). In my opinion, it is difficult to defend the existence of a religion that is always used as an instrument of conflict and which does not abandon self-isolation to build spaces of open encounter and friendship with each religion. Through encounters and friendship, religions could mutually condemn and discourage provocation that leads to conflict relation.

In this context, I am interested in offering what Jonathan P. Case has argued: Christianity is called to build friendly conversations about God with others through the practice of Jesus' table fellowship in the Bible. Jesus ate dinner with those devoted to him and those who denied and betrayed him, those who enjoyed him and those who were trying to trip him up, and in one of his parables, he calls for those people on the margin you would never invite to a banquet to come and have a seat at the table. In Jesus' vision of the Kingdom of God in its fullness, people from all four directions of the earth will take their seats at the great feast, while the chosen (those who always excluded the gentiles) will themselves be excluded (Mt 8:10-12; Lk 13:29) (Case 2019:9-10).
The table fellowship narrative is essential to finding another approach to Christian presence in a pluralistic society and to building relationships between human beings peacefully. However, Case stated that the idea was not a hard exegesis work because the Bible does not give us detailed digressions on how to carry out a nuanced theological conversation with those who disagree with us. But he attempts to tease out a biblical image that he believes to be true to the central theological and ethical trajectory of the Gospel (Case 2019:11). In this article, I prefer to explore the meaning of table fellowship through the socio-historical exegetical analysis of Luke 5:27-32. According to Miroslav Volf, the interpretation of the Bible will help us define Christian identity that can speak to other people outside the boundaries of the Christian community. The Bible is a scripture that tells about a sign of God's revelation from the past for humanity today (Volf 2010:39-40).

There are three ways in the socio-historical exegetical analysing the socio-historical situation of the Gospel of Luke; exploring the meaning of the fellowship table from Luke 5:2732; and constructing the three marks of friendship with the Other. I use the terms mega-space and mega-friendship based on the narrative of Luke 5:27-32 in particular, which differs from the other Synoptic Gospels (Matthew and Mark) in dealing with the large banquet (dokên megalên) between Jesus, Levi, a large number of tax collectors and other people. In Luke's Gospel, this expression does not refer to a meaning based on small and large sizes. Yet, it emphasises the eschatological significance of Jesus' vision to realise the Kingdom of God in the present. James D.G. Dunn mentioned that Jesus' message of the Kingdom of God was already present in a real sense through his ministry (Mt 11:2-6; Lk 11:19-20) and his table fellowship with tax-collectors and sinners (Lk 5:27-32) (Dunn 2006:712). Therefore, the expression of megafriendship in mega-space is an actualization of God's kingdom by making mutual friendship in eternal love between one another and different communities in the entire cosmic created by God.

\section{Socio-historical context of Luke 5:27-32}

In this section, I begin by describing a short introduction about the author and reader of Luke's Gospel. I continue to explain some specific situations closely related to Luke's story regarding table fellowship - which could become a model for the church to be open, friendly and embracing the Other. This context, among others, concerns relations between Jews and non-Jews and the relationship gap between rich and poor (Cassidy 1983:5; Perrin \& Duling 1982:296).

The name Luke is used as a substitute for the author even though I am aware that the authorship of the Gospel is anonymous from the beginning, and it is still debated who the author is (Burkett 2002:196). Luke wrote to the Christian community of the third generation, precisely after Jerusalem's fall in 70, which is about 85/90 A.D (Perrin \& Duling 1982:294). The reader is introduced to the glorious greeting to 
Theophilus (Lk 1:1-4). The greeting refers to a respected gentile leader. Besides, the name Theophilus itself means those who are loved by God, so it can refer to a community that identifies its existence as people who are loved by God and live in an eternal love relationship. Esler (1989:26) explained that by considering Luke's Gospel narrative directed towards the public, the readers of Luke's Gospel could be identified as Christians or local congregations, consisting of both Jews and gentiles who faced various problems, including conflicts between them and the outside world.

\section{The other in Luke's Gospel}

Geographically, the Gospel of Luke mentions that Jesus' activity was centred around the area of Galilee, and his place was Capernaum (Lk 4:23, 31; 7:1; 10:15). This city is on the North Sea of Galilee. At the time of Jesus, this city was once the border area between Herod and King Philip's territories. It had related to the story of the centurion in Luke $7: 1,8$. In Isaiah 8:23, Galilee is referred to as Galilee of the gentiles, as the Jews viewed the gentiles as hostile foreigners. Isaiah refers to the fact that after Assyria conquered the Kingdom of Northern Israel in 721 B.C., causing the Galilee area and its surroundings to have large numbers of Gentiles. Galilee and its environs were regained by the Jewish people when Aristobulus I of the Judas Maccabean group won the gentile revolution in 104-103 B.C. When Roman general Pompey took control of Palestine in 63 B.C., Galilee and its surroundings were again occupied by the majority of gentiles. This is the historical root of the tension between Jews and gentiles, who view each other as hostile strangers. The Jews saw gentiles as people outside the tradition of purity, and they were different, unclean and sinners. In contrast, the Roman authorities saw the Jews as the others, who were different and a threat to be conquered (Theisen \& Merz 1998:169). In this context, Esler (1989:71) mentions table fellowship between Jews and gentiles as one issue in LukeActs that towers above all others as significant for the emergence and subsequent sectarian identity of the type of community for whom Luke wrote.

The next historical context is the relationship gap between rich and poor. One of the socioeconomic dimensions that caused tension in Lukes's community was land tenure. Land ownership determines the social strata in ancient society. Rich people own large areas of land, while poor people are just workers. Landowners have good relations with the authorities because they pay land taxes. From the time of Jesus to the author of the Gospel of Luke, the system of renting land for peasants and poor communities continued to be practised (Lk 20:9-17). The land of Palestine was ruled by the Roman Empire and the king's clients so that the majority of the wealthy population were gentiles, and some landowners came from client-rules. Under the Empire's elite and client rules, there were tax collectors who worked for the government. They were disliked by the Jewish people because they often extorted and demanded higher taxes than they should. Then in the middle strata, there were land tenants, and underneath there were workers, beggars and marginalised people, including robbers, the majority of whom were Jews. People lived in a social structure that was unjust and mutually exclusive (Theisen \& Merz 1998:173). The tension between rich and poor, strong and weak, the authorities and the oppressed was the primary context of Luke"s Gospel (Lk 4:18-19). That is why Luke affirmed his theological vision to preach liberation for the poor and oppressed and hoped for the repentance and fair treatment of the poor by the rich (Cassidy, 1983:21, 34).

\section{Exposition of table fellowship according to Luke 5:27-32}

The pluralistic community, the tensions - both within the community and outside, social and structural injustice contribute to the table fellowship narrative's background. Luke predominantly shows Jesus' ministry in building fellowship through the practice of eating and drinking. These narratives can be seen in Table 1 .

This article focusses on Luke 5:27-39, which is the first narrative of the fellowship table in the Gospel of Luke. This narrative provides a programmatic basis for the entire fellowship table story. Just (1993) explained:

The feast with Levi the tax collector is the first meal in Luke's Gospel and is programmatic for all other meals, introducing the major theme that will be associated with Luke's table fellowship matrix. The community invited to share in the table fellowship of Jesus is made up of the outcast of society, the tax collectors, and the sinners. (pp. 130-131)

The table fellowship story is found in Luke's Gospel and other synoptic gospels (Mk 2:13-17, Mt 9:9-13). The Gospel of Luke has a different narrative way of emphasising a distinctive theological message in response to its literary context. This story was of major importance to the early Christians in understanding the meaning of Jesus' authority and the characteristics of his open and embracing mission

TABLE 1: Table fellowship of Jesus in Luke's writings.

\begin{tabular}{|c|c|c|c|}
\hline No. & Table fellowship & Text & Participant \\
\hline 1 & $\begin{array}{l}\text { Jesus eats with tax } \\
\text { collectors }\end{array}$ & Luke 5:27-32 & Tax collectors and sinners \\
\hline 2 & $\begin{array}{l}\text { Dinner at Simon the } \\
\text { Pharisee's house }\end{array}$ & Luke 7:36-50 & $\begin{array}{l}\text { Pharisees, guests and the } \\
\text { sinful woman }\end{array}$ \\
\hline 3 & Feeds the five thousand & Luke 9:10-17 & $\begin{array}{l}\text { Five thousand males and } \\
\text { disciples }\end{array}$ \\
\hline 4 & $\begin{array}{l}\text { Hospitality at the house of } \\
\text { Martha }\end{array}$ & Luke 10:38-42 & $\begin{array}{l}\text { Martha, Mary and } \\
\text { disciples }\end{array}$ \\
\hline 5 & $\begin{array}{l}\text { Jesus eats at a Pharisee's } \\
\text { house }\end{array}$ & Luke 11:37-54 & Pharisees and teachers \\
\hline 6 & $\begin{array}{l}\text { Sabbath dinner at a } \\
\text { Pharisee's house }\end{array}$ & Luke 14:1-32 & $\begin{array}{l}\text { Pharisees and their } \\
\text { friends }\end{array}$ \\
\hline 7 & $\begin{array}{l}\text { Hospitality at the house of } \\
\text { Zacchaeus }\end{array}$ & Luke 19:1-10 & $\begin{array}{l}\text { Zacchaeus, the tax } \\
\text { collector, and others }\end{array}$ \\
\hline 8 & $\begin{array}{l}\text { Breaking bread at the } \\
\text { passover meal }\end{array}$ & Luke $22: 7$ & Twelve disciples \\
\hline 9 & Breaking bread at Emmaus & Luke 24:13-35 & Two disciples \\
\hline 10 & Supper with the disciples & Luke 24:36-53 & $\begin{array}{l}\text { The } 11 \text { and others with } \\
\text { them }\end{array}$ \\
\hline 11 & $\begin{array}{l}\text { Table fellowship of apostles } \\
\text { in the early church }\end{array}$ & $\begin{array}{l}\text { Acts } 2: 41-47 ; \\
4: 31-37 ; 6: 1-15\end{array}$ & Apostles and believers \\
\hline
\end{tabular}


(Evans 2008:304). According to David L. Balch, this narrative has a close relationship with the Jewish status and social structure in Greco-Roman society. The Jews emphasise the practice of purity, while Luke's Christian community emphasises the importance of building friendships without alienation and discrimination (Balch 2003:1114-1115; Cassidy 1983:73). The friendship that restores and rejects social discrimination, communal, spiritual and religious boundaries represent the message of salvation presented by Jesus as one of the characteristics of realising eschatological expectations in Luke's Gospel (Green 1995:97).

The word eschatology derives from eschatos, the Greek word for 'last'. Biblical writings distinguish the present age or eon as the period of the history in which life is being lived, and the future, coming age or period of transformed existence that God will bring at the end of history. The latter age or eon is sometimes also referred to as the age to come, the Kingdom of God, the new world or messianic age. In the Synoptic Gospels, a different understanding of the eschatology derives from a variant interpretation of Jesus' teaching and preaching about the Kingdom of God. On the one hand, a number of texts have been viewed as indicating that Jesus expected the Kingdom of God to come in the near future (Mt 4:17; 6:10; 10:5-23, Mk 1:14-15; 9:1; 14; 43; Lk 9:26-27; 10:1-12). On the other hand, other gospel texts have been interpreted to mean that Jesus believed the Kingdom of God was already present, realised or actualised in his own person and ministry (Mt 11:11-22, 12:28, Lk 11:20; 17:20-21). In recent discussions, most scholars have tended to affirm that the Gospel authors believed the Kingdom to be already present in some sense in the life and work of Jesus, while also believing that the consummation of the Kingdom in the fuller sense would not come until the Parousia of the Son of Man (Hiers \& Powell 2011:254-255).

In my opinion, the table fellowship narrative is one form of actualising Jesus' vision of the Kingdom of God, as already present in the eschatological vision or proleptic of the future of the kingdom of God. The celebration of the great meal by Jesus with Levi, the tax collectors and others refers to a celebration of friendship that takes place in the Kingdom of God, which covers the universe as a mega-space. Friendship is initiated by God and invites us to build mega-friendship in eternal love in the present as the realisation of a peaceful future. This means that the mega-friendship conducting in the mega-space began from the relationship of God and continues by us and is a realisation from the future to the present. The realisation of friendship is essential in the present as a form of loyalty, waiting for eschatological fulfilment in the future. This is important to emphasise that a mega-friendship in the eschatological vision is a relationship that keeps growing and develops beyond the limit of time and space. In this eschatological perspective, the exposition of Luke 5:27-39 is divided into three parts, namely Jesus comes out and invites Levi, a tax collector; the great banquet (dochên megalên) at the house of Lewi; and celebrating megafriendship with the other.

\section{Jesus comes out and invites Levi, a tax collector (vv. 27-28)}

The table fellowship story in Luke 5:27-32 is a continuation of the previous account of the teaching and healing of a paralysed man in a home. It is not clear whose house is in the preceding story (Lk 5:17-26). After this healing event, the crowd became amazed and glorified God. However, Jesus did not remain in the house. In the Gospels of Mark and Matthew, after the story of healing the paralytic, Jesus went again to another place (paragon), whereas the Gospel of Luke emphasises that Jesus went out of (ekserchomai) the house, looked into the character of Levi (theaomai) and then invited him to become a disciple (Ford 1984:71).

The word ekserchomai has the meaning of referring to the journey of a pilgrim who does not stay in one place, or a wandering journey like the Israelites who came out of Egypt (Ac 7:7) (Thayer 1961:223). Thus, Jesus in this narrative is depicted as a wanderer or a guest who does not remain permanently. After going outside, Jesus saw Levi, who was clearly described as a tax collector, and invited him to follow. Levi then stood, left everything and followed Jesus. The phrase leaving everything behind in the Gospels' narrative is closely related to the meaning of discipleship (cf. Mk 1:18, 20, Lk 18:22, 28). The word 'follows' in Greek, akolouthein, can mean to imitate. The author broadens his meaning, namely participating and committed to something from beginning to the end, including committing himself to the realisation of the eschatological vision of the Kingdom of God, which Jesus embodied by embracing marginalised people (Lk 9:23, 49, 57; 13:33; 14:27; 18:26-30; 22:33) (Evans 2008:292). Levi committed to leaving his job as a tax collector at the tax house and to providing a large feast in his home for Jesus, his friends and embracing others.

The tax collector's identity pinned to Levi from the start, coupled with the information that he was at the tax house, provides an aroma of tension at the beginning of the story. The tax collectors included people who were branded as sinners by the Jewish leaders. The Jews did not like them because of their work as tax collectors, who cooperated with the Roman Empire. González explains (2015:80-81) that Roman Empire, apart from levying taxes through census records as did Emperor Augustus, the duty was also entrusted to tax collectors. The taxes collected include land tax, income tax, transportation tax and public administration tax. They were known to be very corrupt, fraudulent and unfair because they often charged more taxes than they should. They could extort and force the little people to pay taxes according to what they want. Therefore, they were categorised as sinners socially because they acted unjustly and religiously in Judaism because they collaborated with the Roman rulers (Ford 1984:72). However, Luke's narrative of Jesus inviting Levi to follow him, as well as being present at his house to eat with many tax collectors and other people, has significance for Luke's community. 


\section{Great Banquet (dochên megalên) at the house of Lewi (v. 29)}

Levi had provided a great meal both to Jesus and a large number (ochlos) of his friends, tax collectors and others. Food and drink had an essential meaning for the sustainability of life. Besides, a meal is a symbol of participation in one's friendship and service to others. In early Christianity, the feast of Jesus and the disciples before his death (the Lord's Supper) was interpreted as a deed of remembering, participating or sharing in fellowship with the Trinity God who brought salvation to all creation. In the eschatological concept, the meal is a gift from God for salvation and everlasting life in God's Rule (Lk 22:16) (Behm 1964:689). At the Easter meal, God is present and builds a fellowship of love that initiates a deed of God's self-sacrifice for his creation.

The word great supper (dochên megalên) is a Luke speciality missing from Matthew and Mark. Luke often uses this word large banquet (dêipnon mêga - 14:16), with a large room (anágaion mêga - 22:12) to reflect the existence of a large company or large fellowship, which involved a large number (6:17) of guests or invitees. In the preparatory story for the supper evening, the large room is not merely for the presence of many people. Still, it refers to the God's presence, who interrelates in love to build a fellowship of love with the disciples (22:12). The word mega also relates to the almighty God (Mt 5:35), or a sign of being filled with the Holy Spirit, and refers to Jesus, the Son of God most high (Lk 1:15; 32). In the narrative of Acts, this word refers to the Holy Spirit's role who filled Peter, to testify that God is no respecter of persons, but in every nation he that feareth him, and worketh righteousness, is accepted with him (Ac 11:1, 5, 9; cf. Ac 10:34-35) (Legasse 1991:399-400). Thus, we could interpret the great banquet as an eschatological meal that presents God and his government, which embraces all people without differentiating them based on discriminatory social and religious boundaries.

Luke does not explicitly categorise a large number of tax collectors and other people who ate together as sinners. Luke prefers to use the Greek word allôn, which means other people. In Luke's narrative, the others are often described as being like the crowd (ochlos), or people (laos), namely foreigners, poor and sick people, those who are marginalised, those who always follow Jesus to listen to his teachings and the people who stand in stark contrast to their leaders (Kingsbury 1991:29-30). In this passage, Matthew and Mark use the Greek expression harmatôloi, which means sinners were sitting down to eat with Jesus. In Luke, this expression was only said later by the Pharisees and scribes after seeing this event (Just 1993:134). This emphasises that the dining table friendship was an open space that embraced everyone without discriminating against or excluding each other.

\section{Table fellowship: Celebrating mega-friendship with the other (vv. 30-32)}

In the following story, the Pharisees and the scribes came to question why Jesus' disciples were friendly at the dinner table with tax collectors and sinners. According to Ford, every meal was of religious significance for a Jew because it established an ontological union between the dinners. The word dochên is used for important banquets in the Old Testament (Gn 21:8, Isaac's weaning; Gn 26:30, the banquet for the peace covenant between Isaac and Abimelech; Dn 5:1, King Balshazzar's feast for a 1000 of his lords). In the New Testament, it is used only here and in Luke 14:7-14 (Ford 1984:72). Friendship with tax collectors who collaborated with foreign rulers and friendship with foreigners outside of Judaism violated Judaism's tradition of purity (Esler 1989:73). This story leads to criticism on the part of the Pharisees and scribes, who are zealous about the Law; they believe that those who eat with unclean people become unclean themselves (González 2015:81). However, Luke has a different theological vision, namely inviting the church to maintain the mega-space created by God by celebrating mega-friendship with the Other.

Luke has the question addressed to the disciples about their behaviour (in Mark about Jesus' behaviour), even though it is Jesus who replies. Actually, as a host, Levi should be most responsible for responding to the question. It is perhaps because Luke was aware that a similar question about eating with unclean (Gentiles) was a grave issue in the churches (Lk 10:1-11; 18, cf. Gl 2:11-16, 1 Cor 8-10) (Evans 2008:307). That is why Jesus' answer became essential to provide positive and programmatic of Jesus' mission for the church community to build a community that was open to others.

The final two sayings climax the story, 'I have come to call not the righteous but sinners to repentance' (5:32). The formula introduces a reflective summary of the character and purpose of Jesus' mission seen in its totality and as already completed. It is a saying closed to Paul's theology of a God 'who justifies the ungodly' (Rm 4:5), and Christ who 'died for ungodly' (Rm 5:6). Following Jesus does not involve alienation, even maintaining group identity, but instead associating with those who differ (Balch 2003:1115). Only Luke has 'to repentance' (metânoian), in 5:32, a word that is characteristic of his Gospel. Matthew use metânoia and metanoéô seven times, and Mark three times. Luke uses it 14 times $(3: 3,8 ; 5: 32 ; 10: 13 ; 11: 32 ; 13: 3,5 ; 15: 7$ (twice), 10; 16:30; $17: 3,4 ; 24: 47$ ). Luke's use of 'I have not come' (ouk elêlutha) instead of 'I came not' (ouk êlthon) suggests that Jesus' ministry is ongoing: 'I am come', that is, it lasts into the present. His acceptance of the first invitation to dine with tax collectors and the others is invite them 'to repentance' (Just 1993:135). Jesus, who accepts the invitation to build a friendship with Levi, the tax collectors and strangers at the dinner table, also invites all people to experience healing, repentance and renewal of life.

\section{Marks of mega-friendship with the other}

The table fellowship story provides the theological notion of relationship or interrelationship among one another. There is no stranger at breaking the bread, and the wine's pouring 
because the stranger is welcome. The guest, in turn, can be the host. If we look at the life of Jesus, we see that at times he plays the role of both host and guest, including in the story of the feast with Levi, the tax collector in Luke 5:27-39. Based on the interpretation of the story, I explain two marks of megafriendship with the Other as follows.

Firstly, mega-friendship is a form of the real presence of the Kingdom of God. Jesus is the owner of the great banquet, which is celebrated as the embodiment of the eschatological vision of God's reign that he is presenting. God's government embraces, restores, liberates people from oppression, poverty and discrimination and transforms the lives of all those who love to oppress their fellowmen. Jesus manifestly presented the Kingdom of God through friendship at the dinner table. Table friendship is proleptic of fellowship in the future of the Kingdom of God (Lk 22:16). The reign of God presented by Jesus is a vision for the sustainability of the entire life of creation filled with shalom. Thus, mega-friendship is the real realisation of the Kingdom of God, and all people, we, the others, we, the enemies, are embraced by the divine person who loves us with the same love with they love each other and make space for us within their own eternal embrace.

Secondly, the church was sent to continue to build and maintain a mega friendship in its mission in the world. The realisation of God's reign in the mission of Jesus does not mean the end of world history. In the table fellowship narrative, Jesus shows the disciples that the fullness of God's reign will be in the future, and God and humanity will again sit at the table of eschatological friendship (Lk 22:16, 18). In continuing the mission of Jesus, the church is not alone because God who is interrelated in the history of salvation is always with the church until the end of this world's history (Lk 22:27-30). That is why friendly relations through table fellowships are continued by the church (Ac 1:4; 2:42).

In the context of pluralistic society such as in Indonesia, Christianity is called by God to continue realising megaspace as a shared living space with all people in diversity and to build friendly relationships in eternal love. This relationship must not be destroyed only by a selfish attitude of creating conflicts and violence in the name of differences in ethnicity, culture, social groups and religions (Dandirwalu 2016; Pattinama 2020). According to the Indonesian Constitution's statement, all people in Indonesia have acknowledged that: 'By the grace of God the Almighty and driven by a noble desire, so that a free national life, the Indonesian people hereby declare the independence of Indonesian state'. This means that the independent Indonesian state consisting of various ethnicities, nations, languages, cultures and religions is a gift from God (Lestari \& Parihala 2020:51).

Rachel Iwamony explains that Indonesia is a country where many religions existed. The existence of many religions has been supported by the Indonesian constitution, especially Article 29. According to this article, Indonesia State guarantees all its entire citizens to live and to express their religion freely. Precisely, this article guarantees all
Indonesian citizens to live their religion (Iwamony 2019:114). Thus, Indonesia becomes a mega-space where God is present to build relationships within himself and invites all people in diversity to build a friendship to uphold Indonesia's unity.

\section{Conclusion}

The theology of mega-friendship from the table fellowship narrative emphasises that religions have still become sources and inspirations for goodness, peace and friendship that embrace the Other. The mega-friendship initiated by God encourages all of us, both enemies, us and others, to jointly build a space of friendship in eternal love for the sake of sustaining a peaceful life. Mega-friendship is essential for the presence of Christianity with the Other because it was initiated by God and manifested as a real presence of the Kingdom of God in the present, as well as being an inspiration for the church in its mission to befriend all religions in the world. In the context of a pluralistic society in Indonesia, mega-friendship theology emphasises the importance of a life of mutual acceptance and respect for differences to maintain Indonesia's unity.

\section{Acknowledgements}

The author would like to acknowledge Prof. Joas Adiprasetya and Prof. Samuel B. Hakh and academic advisors in Th.D studies at Jakarta Theological Seminary for extending their moral support for this research.

\section{Competing interests}

The author declares that they have no financial or personal relationships that may have inappropriately influenced them in writing this article.

\section{Author's contributions}

Y.P. is the sole author of this article.

\section{Ethical considerations}

This article followed all ethical standards for research without direct contact with human or animal subjects.

\section{Funding information}

This research received no specific grant from any funding agency in the public, commercial or not-for-profit sectors.

\section{Data availability}

Data sharing is not applicable to this article as no new data were created or analysed in this study.

\section{Disclaimer}

The views and opinions expressed in this article are those of the author and do not necessarily reflect the official policy or position of any affiliated agency of the author. 


\section{References}

Adiprasetya, J., 2018, 'The good yet missing innkeeper and the possibility of open ecclesiology', Ecclesiology 14(2), 185-202. https://doi.org/10.1163/1745531601402006

Ariarajah, S.W., 2017, Strangers or co-pilgrims? The impact of interfaith dialogue on Christian faith and practice, Fortress Press, Minneapolis, MN.

Balch, D.L., 2003, 'Luke', in J.D.J. Dunn \& J.W. Rogerson (eds.), Eerdmands commentary on the Bible, pp. 1114-1115, Wm. B. Eerdmans Publishing Co., Grand Rapids, MI.

Behm, J., 1964, 'Estio', in G. Kittel (ed.), Theological dictionary of the New Testament, Vol. II, p. 689, Wm. B. Eerdmans Publishing Co., Grand Rapids, MI.

Burkett, D., 2002, An introduction to the New Testament and the origins of Christianity Cambridge University Press, Cambridge.

Case, J.P., 2019, Around the table: Talking graciously about God, Cascade Books, Eugene, OR.

Cassidy, R.J., 1983, Jesus, politics, and society: A study of Luke's gospel, Orbis Books, Maryknoll, NY.

Cavanaugh, W.T., 2009, The myth of religious violence: Secular ideology and the roots of modern conflict, Oxford University Press, Oxford.

Dandirwalu, R., 2016, 'Totem Ambon Manise: Membongkar Segregasi Agama di Kota Ambon', Antropologi Indonesia 35(1), 30-44. https://doi.org/10.7454/ai. v35i1.5511

Dawkins, R., 2008, The God delusion, Mariner, Wilmington, MA.

Dunn, J.D.G., 2006, 'New Testament theology', in J.W. Rogerson \& J.M. Lieu (eds.), The Oxford handbook of biblical studies, p. 712, Oxford University Press, New York, NY.

Esler, P.F., 1989, Community and gospel in Luke-Acts: The social and political motivations of Lucan theology, Cambridge University Press, Cambridge.

Evans, C.F., 2008, Saint Luke, 2nd edn., SCM Press, London.

Ford, J.M., 1984, My enemy is my guest: Jesus and violence in Luke, Orbis Books, Maryknoll, NY.

Galtung, J., 1996, Peace by peaceful means: Peace and conflict, development, and civilization, Sage, London.

González, J.L., 2015, The story Luke tells: Luke's unique witness to the gospel, Wm. B. Eerdmans Publishing Co., Grand Rapids, MI.

Green, J.B., 1995, New Testament theology: The theology of the Gospel of Luke, Cambridge University Press, Cambridge.

Harris, S., 2004, The end of faith: Religion, terror and the future of reason, Norton New York, NY.
Hiers, R.H. \& Powell, M.A., 2011, 'Eschatology', in The Harper Collins Bible dictionary, rev. edn., HarperOne, San Francisco, CA.

Hitchens, C., 2009, God is not great: How religion poisons everything, Twelve, New York, NY.

Iwamony, R., 2019, 'Majority versus Minority', in Proceedings of the Internationa conference on religion and public civilization (ICRPC 2018), Atlantis Press, Dordrecht, The Netherlands, January, 2019, p. 114.

Juergensmeyer, M., 2017, Terror in the mind of God: The global rise of religious violence, University of California Press, Los Angeles, CA.

Just, A.A., 1993, The ongoing feast: The fellowship and eschatology at Emmaus, The Liturgical Press, Collegeville, MN.

Kingsbury, J.D., 1991, Conflict in Luke: Jesus, authorities, disciples, Fortress Press, Minneapolis, MN.

Legasse, S., 1991, 'Mega', in H. Balz \& G. Schneider (eds.), Exegetical dictionary of the New Testament, Vol. II, pp. 399-400, Wm. B. Eerdmans Publishing Co., Grand Rapids, MI.

Lestari, D.T. \& Parihala, Y., 2020, 'Merawat Damai Antar Umat Beragama Melalui Memori Kolektif dan Identitas Kultural Masyarakat Maluku', Hanifiya: Jurnal Studi Agama-Agama 3(1), 43-54. https://doi.org/10.15575/hanifiya.v3i1.8697

Natar, A.N., 2019, 'Trauma Healing bagi Perempuan Korban Konflik: Belajar dari Konflik Maluku dan Poso', DUNAMIS: Jurnal Teologi dan Pendidikan Kristiani 4(1), a205. https://doi.org/10.30648/dun.v4i1.205

Parihala, Y. \& Busro, B., 2020, 'Reclaiming Jesus as source of peace in Luke 12:49-53 through the perspective of religious pluralism in an Indonesian context', HTS Teologiese Studies/Theological Studies, 76(4), a6088. https://doi.org/10.4102/ hts.v76i4.6088

Pattinama, E., 2020, 'Identitas multikultural salam - Sarani di maluku sebagai model memelihara integrasi bangsa', ARUMBAE: Jurnal Ilmiah Teologi dan Studi Agama 2(1), a413. https://doi.org/10.37429/arumbae.v2i1.413

Perrin, N.\& Duling, D.C., 1982, The New Testament: An introduction, Harcourt Brace Jovanovich Inc., New York, NY.

Setyawan, Y.B., 2017, 'Konflik dan Kekerasan Bernuansa Agama di Indonesia Dalam Perspektif Pandangan Yesus dalam Injil-Injil Kanonis Perjanjian Baru', in Y.B. Setyawan, N. Souisa, S. Gaspersz \& R. Lesawengan (eds.), Perdamaian dan Keadilan, pp. 1-36, BPK Gunung Mulia, Jakarta.

Thayer, J.H., 1961, Greek - Englis Lexicon of the New Testament, 4th edn ed. J. H. Thayer, T\&T Clark, Edinburgh.

Theissen, G. \& Merz, A., 1998, The historical Jesus: A comprehensive Guide, SCM Press, London.

Volf, M., 2010, Captive to the word of God: Engaging the scriptures for contemporary theological reflection, Wm. B. Eerdmans Publishing Co., Grand Rapids, MI. 